\title{
Dulaglutide: an evidence-based review of its potential in the treatment of type 2 diabetes
}

\author{
This article was published in the following Dove Press journal: \\ Core Evidence \\ 9 January 2015 \\ Number of times this article has been viewed
}

\section{Krystal L Edwards' \\ Molly G Minze 2}

'Ambulatory Care Division, Department of Pharmacy Practice, School of Pharmacy, Texas Tech University Health Sciences Center, Dallas, TX, USA; ${ }^{2}$ Ambulatory Care Division, Department of Pharmacy Practice, School of Pharmacy, Texas Tech University Health Sciences Center, Abilene, TX, USA
Correspondence: Krystal L Edwards Texas Tech University Health Sciences Center, School of Pharmacy, 4500 S Lancaster Rd, Bldg 7, Rt \#I I 9A, Dallas, TX 75216, USA

Tel + I 214358905 I

Fax +I 2 I43725020

Email krystal.edwards@ttuhsc.edu
Introduction: As the prevalence of type 2 diabetes mellitus (T2DM) is anticipated to continue to rise worldwide, so too are the treatment options also continuing to expand. Current guidelines recommend individualized treatment plans which allow for provider choice and diversity of pharmacotherapeutic regimens. The glucagon-like peptide-1 receptor agonist (GLP-1 RA) class is rapidly expanding, with dulaglutide (Trulicity ${ }^{\mathrm{TM}}$ ) as a once-weekly agent recently approved.

Aims: This article examines the evidence currently available on the efficacy and safety of dulaglutide for use in T2DM.

Evidence review: Dulaglutide has been shown to have similar efficacy and safety to other newer GLP-1 RAs, and better glycemic control than placebo. It lowers glycated hemoglobin $\left(\mathrm{A}_{1 \mathrm{c}}\right)$, fasting and postprandial glucose levels, and promotes weight loss when used as first-, second-, or third-line therapy. It has also been shown to improve $\beta$-cell function and provide cardiovascular benefits, such as lower blood pressure and improved lipid levels. Dulaglutide also has a low risk for hypoglycemia and a similar adverse effect profile to other GLP-1 RAs in the class, with transient gastrointestinal problems and potential risk for pancreatitis.

Place in therapy: While long-term data on safety and efficacy are forthcoming, dulaglutide is positioned to be placed at the same level as other GLP-1 RAs in the class: as second-line therapy in addition to diet and exercise in those patients who cannot achieve glycemic control on monotherapy metformin. It may also be useful as first-line therapy instead of metformin.

Conclusion: Dulaglutide is a once-weekly GLP-1 RA approved for the treatment of T2DM that has shown similar efficacy to other agents in this class.

Keywords: GLP-1 RA, glucagon-like peptide-1 receptor agonist, incretin mimetic, type 2 diabetes mellitus therapy

Core evidence clinical impact summary for dulaglutide 0.75 and $1.5 \mathrm{mg}$ onceweekly in the treatment of type 2 diabetes

\begin{tabular}{|c|c|c|}
\hline $\begin{array}{l}\text { Outcome } \\
\text { measure }\end{array}$ & Evidence & Implications \\
\hline \multicolumn{3}{|c|}{ Disease-oriented evidence } \\
\hline Reduction in $\mathrm{A}_{\mathrm{Ic}}$ & $\begin{array}{l}\text { Randomized } \\
\text { controlled trials } \\
\text { (RCTs) demonstrate } \\
A_{\text {Ic }} \text { reductions of } \\
0.7 \% \text { to } 1.5 \%\end{array}$ & $\begin{array}{l}\text { In patients with T2DM, dulaglutide significantly } \\
\text { improves glycemic control compared with } \\
\text { placebo and other antidiabetic agents by } \\
\text { decreasing } A_{\text {Ic }} \text { as monotherapy, in combination } \\
\text { with metformin, and as add-on therapy with } \\
\text { metformin and other antidiabetic agents. }\end{array}$ \\
\hline
\end{tabular}




\begin{tabular}{|c|c|c|}
\hline $\begin{array}{l}\text { (Continued) } \\
\text { Outcome } \\
\text { measure }\end{array}$ & Evidence & Implications \\
\hline $\begin{array}{l}\text { Reduction in fasting } \\
\text { plasma glucose (FPG) } \\
\text { and postprandial } \\
\text { glucose (PPG) }\end{array}$ & $\begin{array}{l}\text { RCTs show FPG } \\
\text { decreases of I } 3 \text { to } \\
43 \mathrm{mg} / \mathrm{dL} \text { and PPG } \\
\text { lowering of } 4 \text { I to } \\
46 \mathrm{mg} / \mathrm{dL}\end{array}$ & $\begin{array}{l}\text { In patients with T2DM, dulaglutide significantly } \\
\text { improves glycemic control compared with placebo } \\
\text { and other antidiabetic agents by decreasing FPG } \\
\text { and PPG as monotherapy, in combination with } \\
\text { metformin, and as add-on therapy with metformin } \\
\text { and other antidiabetic agents. }\end{array}$ \\
\hline $\begin{array}{l}\text { Glycemic } \\
\text { control }\end{array}$ & $\begin{array}{l}\text { RCTs demonstrate } \\
\text { that } 55 \%-78 \% \text { of } \\
\text { patients reached } \\
A_{\mathrm{Ic}} \leq 7 \%\end{array}$ & $\begin{array}{l}\text { In patients with T2DM, significantly more } \\
\text { patients achieve } A_{\text {Ic }} \text { goal of } \leq 7 \% \text { on dulaglutide } \\
\text { monotherapy compared with placebo and } \\
\text { metformin monotherapy, as well as on } \\
\text { dulaglutide in addition to metformin and/or } \\
\text { other antidiabetic medications when compared } \\
\text { to placebo, sitagliptin, and exenatide. }\end{array}$ \\
\hline $\begin{array}{l}\text { Improvement } \\
\text { in } \beta \text {-cell } \\
\text { function }\end{array}$ & $\begin{array}{l}\text { RCTs show } \\
\text { improvement in } \\
\text { homeostasis model } \\
\text { assessment (HOMA) } \\
\text { 2-B }\end{array}$ & $\begin{array}{l}\text { Dulaglutide has demonstrated improvements } \\
\text { in } \beta \text {-cell function via increased HOMA2-B as } \\
\text { monotherapy, in combination with metformin, } \\
\text { and as add-on therapy with metformin and } \\
\text { other antidiabetic agents. }\end{array}$ \\
\hline \multicolumn{3}{|c|}{ Patient-oriented evidence } \\
\hline Hypoglycemia & $\begin{array}{l}\text { RCTs demonstrate } \\
\text { low rates of } \\
\text { hypoglycemia and no } \\
\text { severe hypoglycemia }\end{array}$ & $\begin{array}{l}\text { Dulaglutide as monotherapy, in combination } \\
\text { with metformin, or as add-on therapy with } \\
\text { metformin and other antidiabetic agents } \\
\text { demonstrated low frequency of hypoglycemia. }\end{array}$ \\
\hline $\begin{array}{l}\text { Weight } \\
\text { change }\end{array}$ & $\begin{array}{l}\text { RCTs show weight } \\
\text { loss of } 1.3-3 \mathrm{~kg}\end{array}$ & $\begin{array}{l}\text { In T2DM patients, dulaglutide promotes } \\
\text { weight loss. }\end{array}$ \\
\hline Tolerability & $\begin{array}{l}\text { Gastrointestinal }(\mathrm{Gl}) \\
\text { side effects have } \\
\text { been seen in clinical } \\
\text { trials with limited } \\
\text { reports of pancreatitis }\end{array}$ & $\begin{array}{l}\text { Dulaglutide is generally well tolerated with } \\
\text { transient Gl side effects greater than those of } \\
\text { placebo and sitagliptin but similar to metformin } \\
\text { and other GLP-I RAs. There is potential risk for } \\
\text { pancreatitis. }\end{array}$ \\
\hline $\begin{array}{l}\text { Cardiovascular (CV) } \\
\text { effects }\end{array}$ & $\begin{array}{l}\text { RCTs demonstrate } \\
\text { reductions in blood } \\
\text { pressure, total } \\
\text { cholesterol, low- } \\
\text { density lipoprotein } \\
\text { (LDL) cholesterol, and } \\
\text { triglycerides }\end{array}$ & $\begin{array}{l}\text { Dulaglutide has demonstrated positive } \mathrm{CV} \\
\text { benefits in T2DM patients. }\end{array}$ \\
\hline $\begin{array}{l}\text { Patient } \\
\text { adherence }\end{array}$ & No RCTs available & $\begin{array}{l}\text { Studies are required to assess the effects of } \\
\text { dulaglutide on adherence to treatment. }\end{array}$ \\
\hline Economic evidence & No RCTs available & Currently unknown. \\
\hline
\end{tabular}

\section{Introduction}

According to the International Diabetes Federation in 2013, 328 million people are currently diagnosed with diabetes and there is a projected rise of $55 \%$ to 592 million people in the world living with diabetes by the year 2035. ${ }^{1}$ The greatest rise is projected to occur in Africa, the Middle East, Southeast Asia, and South and Central America, with a greater than $50 \%$ increase projected in each of these areas. ${ }^{1}$ Treatment options for diabetes continue to increase to provide more individualized treatment for patients with type 2 diabetes mellitus (T2DM).

Glucagon-like peptide-1 (GLP-1) receptor agonists (RAs) are part of the incretin mimetic diabetes treatment options.
Endogenous GLP-1 is an incretin hormone that is released from the intestine in response to food intake. GLP-1 effects include increased insulin secretion, decreased glucagon release, increased satiety and slowed gastric emptying. ${ }^{2-4}$ GLP-1 is degraded by dipeptidyl peptidase-IV (DPP-4) in the human body within minutes of release, thereby causing a limitation in replication of this incretin hormone. Currently, exenatide, exenatide long-acting release (LAR), liraglutide, albiglutide, and lixisenatide are available in the United States and/or Europe, with exenatide first available as a twice-daily formulation approved in April of 2005. Since that time, additional formulations have offered once-daily (liraglutide and lixisenatide) and once-weekly (exenatide LAR 
and albiglutide) dosing strategies. Dulaglutide was recently approved as a once-weekly GLP-1 RA.

A review of national guidelines for use of GLP-1 RAs demonstrates a variance in opinion for the place in therapy for these agents. The American Diabetes Association/European Association for the Study of Diabetes places GLP-1 RAs as second- and third-line therapy. ${ }^{5}$ They state that these agents have a high efficacy for lowering glycated hemoglobin $\left(\mathrm{A}_{1 \mathrm{c}}\right)$, a low risk for hypoglycemia, promote weight loss, include gastrointestinal (GI) side effects, and have a high cost compared to the other second- and third-line agents, including insulin, sulfonylureas, thiazolidinediones, and DPP-4 inhibitors. The American Association of Clinical Endocrinology promotes metformin as first-line therapy, but lists GLP-1 RAs as an option here as well in place of metformin, along with being the preferred second- and third-line option in addition to metformin therapy. ${ }^{6}$ They too base this on a high $\mathrm{A}_{1 \mathrm{c}}$ lowering property, promotion of weight loss, low risk for hypoglycemia, and their ability to reduce pre- and postprandial glucose levels; they also state that they are available in several formulations. The UK's National Institute for Health and Clinical Excellence guideline was last updated in 2009. ${ }^{7}$ It recommends GLP-1 RAs as third-line therapy after metformin and sulfonylureas if: a patient has a body mass index $(\mathrm{BMI}) \geq 35.0 \mathrm{~kg} / \mathrm{m}^{2}$ and has specific psychological or medical problems associated with high body weight; or a patient has a BMI $<35.0 \mathrm{~kg} / \mathrm{m}^{2}$ and therapy with insulin would not be permitted due to the patient's occupation; or weight loss would be beneficial for obesity-related comorbidities.

\section{Current place in therapy}

As previously described, GLP-1 RAs mimic the release of endogenous GLP-1 after a meal or oral glucose load. ${ }^{2-4}$ This "incretin effect" is the process where more insulin secretion occurs when glucose is administered orally than when the same amount of glucose is administered intravenously. ${ }^{4,8}$ This is a glucose-dependent action and occurs by increasing the $\beta$-cell's sensitivity to glucose while preventing its apoptosis, exerting weight loss through satiety. ${ }^{49}$ Patients with T2DM have an impaired response to endogenous GLP-1 action, but this can be overcome through pharmacological doses of GLP-1. ${ }^{4}$

As discussed, current guideline recommendations place GLP-1 agonists as second-line therapy behind first-line metformin for the majority of patients with T2DM. ${ }^{5,6}$ When used as monotherapy or as add on therapy to existing regimens, the currently marketed GLP-1 agonist exenatide twice-daily monotherapy lowered $\mathrm{A}_{1 \mathrm{c}}$ by 0.4 to $1.6 \%$, and liraglutide alone or in combination with glimepiride, metformin and rosiglitazone, and long acting insulin was found to lower $\mathrm{A}_{1 \mathrm{c}}$ by 0.9 to $1.5 \% .^{10-14}$ Dulaglutide was found to lower $\mathrm{A}_{1 \mathrm{c}}$ from by 0.9 to $1 \%$ in a dose-dependent fashion when used as monotherapy in a 12 -week placebo-controlled dose-response trial in patients who had discontinued metformin. ${ }^{15}$ In a pharmacokinetic and pharmacodynamic safety and tolerability trial, dulaglutide reduced $\mathrm{A}_{1 \mathrm{c}}$ by 0.2 to $1.2 \%$ over 5 weeks in patients using diet and exercise alone or who were on monotherapy. ${ }^{16}$ In uncontrolled patients taking metformin, dulaglutide reduced $\mathrm{A}_{1 \mathrm{c}}$ more significantly over sitagliptin, with dulaglutide $1.5 \mathrm{mg}$ reducing $\mathrm{A}_{1 \mathrm{c}}$ by $1.1 \% \pm 0.06 \%$ and dulaglutide $0.75 \mathrm{mg}$ reducing $\mathrm{A}_{1 \mathrm{c}}$ by $0.87 \% \pm 0.06 \%$ versus sitagliptin reducing $\mathrm{A}_{1 \mathrm{c}}$ by $0.39 \% \pm 0.06 \%(P<0.001) .{ }^{17}$ On average, the $A_{1 c}$ lowering potential for GLP-1 RAs is approximated at $1 \%-1.5 \%{ }^{3}$

Traditionally, GLP-1 RAs have lowered both fasting and postprandial plasma glucose, and each formulation differs in the extent to which it lowers the glucose level. Short-acting GLP-1 RAs predominantly lower postprandial plasma glucose (exenatide short acting, lixisenatide) through slowing gastric emptying, whereas long-acting GLP-1 RAs lower blood glucose by stimulating insulin secretion and reducing glucagon (dulaglutide, liraglutide, albiglutide, exenatide LAR). ${ }^{8}$ Dulaglutide reduces both fasting and postprandial glucose when compared to placebo in uncontrolled patients who have failed oral antidiabetic medications. ${ }^{18}$ As a onceweekly GLP-1 RA formulation, dulaglutide has been shown to have a more robust effect on fasting plasma glucose than postprandial blood glucose. Despite the lowering of plasma glucose, significant hypoglycemia is not demonstrated with GLP-1 RAs secondary to the glucose-dependent mechanism, which is considered a benefit to this class of medications. ${ }^{19}$

In contrast to guidelines previously discussed, the 2007 Institute for Quality and Economic Efficiency in Health Care found the glucose-lowering effect of the GLP-1 exenatide twice daily to be similar to that of insulin glargine or insulin aspart, without additional benefit, including benefits to quality of life or treatment satisfaction. ${ }^{20}$ This report also found the impact of weight loss to be unclear, with occurrence of harmful GI adverse events. ${ }^{20}$ Since the publishing of this 2007 report, additional agents within this class have come to market and GLP-1 RAs are currently recommended as second-line therapies. ${ }^{5,6}$

\section{Clinical efficacy Monotherapy}

Dulaglutide, a once-weekly injectable (given via subcutaneous administration) GLP-1 RA was approved in 
September 2014 by the Food and Drug Administration (FDA) in the United States and November 2014 by the European Commission based upon published trials summarized below (Table 1). ${ }^{15,17,18,21-23}$ Most trials compare dulaglutide to placebo in addition to first-line metformin therapy and have demonstrated promising $\mathrm{A}_{1 \mathrm{c}}$ reductions for dulaglutide. Grunberger et al completed a 12-week doubleblind, placebo-controlled study in $167 \mathrm{~T} 2 \mathrm{DM}$ patients $\left(\mathrm{A}_{1 \mathrm{c}}\right.$ $7.2 \% \pm 0.6 \%$, duration of diabetes: 3.9 years) who had either received metformin therapy or were treatment naïve. ${ }^{15}$ Patients were randomized to one of five treatment arms (placebo, $0.1 \mathrm{mg}, 0.5 \mathrm{mg}, 1 \mathrm{mg}$, or $1.5 \mathrm{mg}$ dulaglutide) in a $1: 1: 1: 1: 1$ manner with the primary endpoint being change from baseline $\mathrm{A}_{1 \mathrm{c}}$ and secondary endpoints being efficacy and safety. Results demonstrated a dose-dependent $\mathrm{A}_{1 \mathrm{c}}$ reduction $(P<0.001$ for all $)$ for dulaglutide and greater reduction compared to placebo $(P<0.001$ for all) except for in the $0.1 \mathrm{mg}$ dose. Similar results were seen for daily plasma glucose and fasting plasma glucose (FPG) with dose-dependent reductions for all $(P<0.001)$ which were greater when compared to placebo $(P<0.001)$ except for the $0.1 \mathrm{mg}$ dose. More patients receiving dulaglutide achieved $\mathrm{A}_{1 \mathrm{c}}$ reductions of $\leq 7 \%(P<0.001)$ or $\leq 6.5 \%(P<0.001)$ than those receiving placebo. Dose-dependent increases in the homeostasis model assessment (HOMA)2-B (a marker of basal beta-cell function to release insulin during the fasting state) were seen with all dulaglutide groups $(P=0.036)$ and were greater than that for placebo except for the $0.1 \mathrm{mg}$ dose $(P \leq 0.013)$; no changes were noted for any group for HOMA2-S (an assessment of insulin sensitivity). Body-weight reductions were noted for all dulaglutide groups with dose-dependent results; however, these were not significant when compared to placebo. Safety data showed treatment-emergent adverse drug events (ADEs) included nausea, diarrhea, and nasopharyngitis, with four patients discontinuing dulaglutide due to ADEs. Four cases of serious ADEs, with two of these linked to study drugs, included hemorrhagic pancreatitis associated with cholelithiasis (placebo) and abdominal pain/distension (dulaglutide $1.5 \mathrm{mg}$ ). No reports of severe hypoglycemia were noted, with rates of hypoglycemia similar across all groups. Both diastolic and systolic blood pressures were similar across all groups, along with levels of pancreatic enzymes being similar between groups at endpoint. One treatment-emergent case of anti-dulaglutide antibody (dulaglutide $1 \mathrm{mg}$ ) was reported, along with one patient reporting treatment-emergent skin rash and skin exfoliation (dulaglutide $0.1 \mathrm{mg}$ ). Overall, this study demonstrated

Table I Clinical trial review

\begin{tabular}{|c|c|c|c|c|c|c|c|}
\hline Study & Arms (n) & $\begin{array}{l}\text { Baseline } \\
\mathbf{A}_{\mathrm{Ic}}(\%)\end{array}$ & $\begin{array}{l}\text { Change in } \\
A_{\text {Ic }}(\%)\end{array}$ & $\begin{array}{l}\% \text { reached } \\
\mathbf{A}_{\mathrm{Ic}}<\mathbf{7 \%}\end{array}$ & $\begin{array}{l}\% \text { reached } \\
A_{I c} \leq 6.5 \%\end{array}$ & $\begin{array}{l}\text { Change in } \\
\text { FPG (mg/dL) }\end{array}$ & $\begin{array}{l}\text { Change in } \\
\text { weight (kg) }\end{array}$ \\
\hline Monotherapy - initial & Placebo (32) & $7.4 \pm 0.6$ & 0.01 & $21^{\mathrm{b}}$ & $7^{\mathrm{b}}$ & -4 & $-1.4 \pm 0.5$ \\
\hline \multirow[t]{4}{*}{ or Metf failure ${ }^{15}$} & Dula 0.I mg QW (35) & $7.1 \pm 0.6$ & -0.37 & $47^{\mathrm{b}}$ & $15^{\mathrm{b}}$ & -8 & $-0.2 \pm 0.4$ \\
\hline & Dula 0.5 mg QW (34) & $7.2 \pm 0.6$ & $-0.89^{a}$ & $73^{b}$ & $53^{b}$ & $-26^{a}$ & $-0.3 \pm 0.4$ \\
\hline & Dula I mg QW (34) & $7.3 \pm 0.7$ & $-1.04^{a}$ & $75^{b}$ & $50^{\mathrm{b}}$ & $-30^{\mathrm{a}}$ & $-1.1 \pm 0.4$ \\
\hline & Dula I.5 mg QW (29) & $7.3 \pm 0.4$ & $-1.04^{a}$ & $7 I^{b}$ & $52^{\mathrm{b}}$ & $-34^{\mathrm{a}}$ & $-1.5 \pm 0.5$ \\
\hline Monotherapy - prior Tx & Metf 2,000 mg daily (268) & $7.6 \pm 0.8$ & $-0.56 \pm 0.06$ & 54 & 30 & $-24 \pm 2$ & $-2.22 \pm 0.24$ \\
\hline with two OAM failure ${ }^{21}$ & Dula 0.75 mg QW (270) & $7.6 \pm 0.9$ & $-0.71 \pm 0.06^{c}$ & $63^{c}$ & $40^{c}$ & $-26 \pm 2$ & $-1.36 \pm 0.24$ \\
\hline (26-wk data) & Dula I.5 mg QW (269) & $7.6 \pm 0.9$ & $-0.78 \pm 0.06^{c}$ & $62^{\mathrm{c}}$ & $46^{c}$ & $-29 \pm 2$ & $-2.29 \pm 0.24$ \\
\hline Combination therapy & Placebo (66) & $8.05 \pm 0.8$ & $\mathrm{NR}$ & NR & NR & -9 & $-0.12 \pm 0.39$ \\
\hline \multirow[t]{3}{*}{ with 2 OAM $^{18}$} & Dula $0.5 / \mathrm{I} \mathrm{mg}$ QW (66) & $8.25 \pm 0.9$ & $-1.38 \pm 0.12^{\mathrm{a}}$ & $49 \%-54 \%$ & $29 \%-32 \%$ & $-38^{a}$ & $-1.44 \pm 0.39 \mathrm{~b}$ \\
\hline & Dula I/I mg QW (65) & $8.25 \pm 1$ & $-1.32 \pm 0.12^{\mathrm{a}}$ & for all & for all & $-37^{a}$ & $-1.34 \pm 0.39^{b}$ \\
\hline & Dula I/2 mg QW (65) & $8.43 \pm 1$ & $-1.59 \pm 0.12^{\mathrm{a}}$ & & & $-48^{a}$ & $-2.55 \pm 0.4^{\mathrm{a}, \mathrm{b}}$ \\
\hline Combination therapy & Placebo (177) & $8.1 \pm 1.1$ & $0.03 \pm 0.07$ & $21^{a}$ & 13 & NR & NR \\
\hline \multirow[t]{4}{*}{ with Metf ${ }^{17}$ (26-wk data) } & Sita 100 mg daily (3I5) & $8.1 \pm 1.1$ & $-0.6 I \pm 0.05$ & $38^{e}$ & $22^{\mathrm{e}}$ & NR & $-1.53 \pm 0.22$ \\
\hline & Dula 0.75 mg QW (302) & $8.2 \pm 1.1$ & $-1.01 \pm 0.6^{\mathrm{a}, \mathrm{d}}$ & $55^{\mathrm{d}}$ & $31^{d}$ & $-13^{d}$ & $-2.6 \pm 0.23^{d}$ \\
\hline & Dula I.5 mg QW (304) & $8.1 \pm I .1$ & $-1.22 \pm 0.05^{\mathrm{a}, \mathrm{d}}$ & $6 I^{d}$ & $47^{d}$ & $-26^{d}$ & $-3.03 \pm 0.22^{\mathrm{d}}$ \\
\hline & & & & & & $(52 w k)$ & $(52 w k)$ \\
\hline Combination therapy & Placebo (|4I) & $8.1 \pm 1.3$ & $-0.46 \pm 0.08$ & 43 & 24 & $-5 \pm 3$ & $1.24 \pm 0.37$ \\
\hline with Metf and $\mathrm{Pio}^{22}$ & Exen 10 mcg BID (276) & $8.1 \pm 1.3$ & $-0.99 \pm 0.60^{\mathrm{a}}$ & 52 & 38 & $-24 \pm 2^{\mathrm{a}}$ & $-1.07 \pm 0.29^{a}$ \\
\hline \multirow{2}{*}{ (26-wk data) } & Dula 0.75 mg QW (280) & $8.1 \pm 1.2$ & $-1.3 \pm 0.6^{\mathrm{aff}}$ & $68^{\mathrm{a}, \mathrm{f}}$ & $53^{\mathrm{a}, \mathrm{f}}$ & $-34 \pm 2^{\mathrm{a}, \mathrm{f}}$ & $0.2 \pm 0.29$ \\
\hline & Dula I.5 mg QW (279) & $8.1 \pm 1.3$ & $-\mid .5 I \pm 0.06^{\mathrm{a}, \mathrm{f}}$ & $78^{\mathrm{a}, \mathrm{f}}$ & $63^{\mathrm{a}, \mathrm{f}}$ & $-43 \pm 2^{\mathrm{a}, \mathrm{f}}$ & $-1.3 \pm 0.29^{a}$ \\
\hline Combination therapy & Dula I.5 mg QW (299) & $8.1 \pm 0.8$ & $-1.42 \pm 0.05^{8}$ & 68 & 55 & $-35 \pm 2$ & $-2.9(0.22)^{\mathrm{h}}$ \\
\hline with Metf ${ }^{23}$ & Lira I.8 mg daily (300) & $8.1 \pm 0.8$ & $-1.36 \pm 0.05$ & 68 & 51 & $-1.9 \pm 2$ & $-3.61(0.22)$ \\
\hline
\end{tabular}

Notes: $0.5 / \mathrm{l} \mathrm{mg}, 0.5 \mathrm{mg}$ titrated to I mg; I/I mg, I mg continued on I mg during titration; I/ $2 \mathrm{mg}, \mathrm{I} \mathrm{mg}$ titrated to $2 \mathrm{mg}$. a $P<0.00 \mathrm{I}$ versus placebo; ${ }^{\text {b }} P<0.00 \mathrm{I}$; $\mathrm{c} P<0.05$ versus metformin; ${ }^{d} P<0.00$ I versus sitagliptin; ${ }^{e} P<0.005$ versus placebo; ${ }^{f} P<0.00$ I versus exenatide; ${ }^{8} P<0.00$ I for noninferiority versus liraglutide; ${ }^{h} P=0.0$ II versus liraglutide. Abbreviations: $A_{I c}$, glycated hemoglobin; BID, twice daily; Dula, dulaglutide; Exen, exenatide; FPG, fasting plasma glucose; Lira, liraglutide; Metf, metformin; NR, not reported; OAM, oral antidiabetic medications; Pio, pioglitazone; QW, once weekly; Sita, sitagliptin; Tx, treatment; wk, week. 
safety and efficacy for the dulaglutide $0.5,1$, and $1.5 \mathrm{mg}$ once-weekly dosages compared to placebo.

Umpierrez et al compared dulaglutide to metformin therapy in a 52-week double-blind, parallel-arm, randomized trial in 807 T2DM patients (baseline $\mathrm{A}_{1 \mathrm{c}} 7.6 \%$, duration of diabetes: 3 years) who were uncontrolled for diet and exercise alone or on one oral antidiabetic agent for $\geq 3$ months. ${ }^{21}$ Patients' former medications were discontinued and they were randomized to once-weekly dulaglutide $1.5 \mathrm{mg}$ or $0.75 \mathrm{mg}$, or metformin 1,500-2,000 mg daily, with the primary noninferiority outcome of change from baseline $\mathrm{A}_{1 \mathrm{c}}$ at 26 weeks. All three treatments reduced $\mathrm{A}_{1 \mathrm{c}}$ by less than $1 \%$ with the greatest least-squares mean (LSm) change in the $1.5 \mathrm{mg}$ dulaglutide arm, which was statistically greater than that of the metformin group $(P=0.002)$. The dulaglutide $0.75 \mathrm{mg}$ arm also had a greater change than metformin. At 52 weeks, the LSm decrease in A1c for the dulaglutide $1.5 \mathrm{mg}$ and $0.75 \mathrm{mg}$, and metformin arms were $-0.7 \pm 0.07$ vs $-0.55 \pm 0.07$ vs $-0.51 \pm 0.07 \%$ with the greatest reduction in the dulaglutide $1.5 \mathrm{mg}$ arm $(P=0.02)$. At 26 weeks, more patients reached an $\mathrm{A}_{1 \mathrm{c}}$ of $\leq 7 \%$ with dulaglutide 1.5 and $0.75 \mathrm{mg}$ than with metformin ( $P=0.02$ for both). The same was seen for $\mathrm{A}_{1 \mathrm{c}}$ of $\leq 6.5 \%(P<0.001$ and $P=0.011$ for dulaglutide $1.5 \mathrm{mg}$ and $0.75 \mathrm{mg}$, respectively, versus metformin). Similar results for reaching $\mathrm{A}_{1 \mathrm{c}}$ goals were seen for dulaglutide $1.5 \mathrm{mg}$ compared to metformin at 52 weeks $(P \leq 0.01$ for both). Changes in LSm FPG were similar at 26 weeks but were greater for dulaglutide $1.5 \mathrm{mg}$ at 52 weeks $(P=0.025$ dulaglutide $1.5 \mathrm{mg}$ versus metformin). No difference in postprandial glucose levels were seen at 26 weeks. Weight loss was similar for dulaglutide $1.5 \mathrm{mg}$ and metformin at both 26 weeks and 52 weeks, but compared to dulaglutide $0.75 \mathrm{mg}$ at both 26 and 52 weeks, metformin had greater loss ( $P=0.003$ [26 weeks] and $P=0.001$ [52 weeks]). HOMA2-B increased in all arms at 26 weeks with greater changes in the dulaglutide arms than in metformin $(P<0.01$ for both). HOMA2-S was the opposite, with the greater change in metformin compared to dulaglutide $(P=0.001$ for dulaglutide $1.5 \mathrm{mg}$ and $P=0.01$ for dulaglutide $0.75 \mathrm{mg}$ ). Similar results were seen for 52 weeks except that the difference between dulaglutide $1.5 \mathrm{mg}$ and metformin for HOMA2-S was no longer significant. There were no serious ADEs and no deaths in the study. Nausea, diarrhea, and vomiting were the most common side effects, with the majority being mild to moderate in severity and no difference between the groups. Overall, hypoglycemia was similar (12.3\% for $1.5 \mathrm{mg}$ dulaglutide, $11.1 \%$ for $0.75 \mathrm{mg}$ dulaglutide, and $12.7 \%$ for metformin) with no severe hypoglycemic episodes. No cases of pancreatitis or pancreatic cancer were noted during the study. Blood pressure changes, both diastolic and systolic, were similar in all three arms. Two percent of patients $(n=10)$ developed treatment-emergent dulaglutide antidrug antibodies with no reported systemic hypersensitivity reactions. Overall, this study demonstrated that dulaglutide $1.5 \mathrm{mg}$ had similar to slightly better reduction of $\mathrm{A}_{1 \mathrm{c}}$ and a greater percentage of patients reaching goal than metformin, with similar efficacy for the $0.75 \mathrm{mg}$ dosage. ADEs were also similar, demonstrating safe and effective use of dulaglutide as monotherapy in the early treatment of T2DM.

\section{Combination therapy}

In another placebo-controlled study, 262 overweight/obese (BMI 33.9 $\left.\pm 4.1 \mathrm{~kg} / \mathrm{m}^{2}\right)$ T2DM patients $\left(\mathrm{A}_{1 \mathrm{c}} 8.24 \% \pm 0.93 \%\right.$, duration of diabetes: 7.5-9 years) who failed to meet $\mathrm{A}_{1 \mathrm{c}}$ goal $<7 \%$ on oral antidiabetic medications were randomized to dulaglutide $0.5 \mathrm{mg}$ titrated to $1 \mathrm{mg}$, dulaglutide $1 \mathrm{mg}$, dulaglutide $1 \mathrm{mg}$ titrated to $2 \mathrm{mg}$, or placebo groups. ${ }^{18}$ Patients continued their two oral antidiabetic medications (sulfonylurea, biguanide, thiazolidinedione, or DPP-4 inhibitors). The primary endpoint of change in $\mathrm{A}_{1 \mathrm{c}}$ (LSm) was greater in each of the dulaglutide doses compared to placebo $(P<0.001$ for all), ranging from $-1.32 \%$ to $-1.59 \%$. The proportions of patients achieving $\mathrm{A}_{1 \mathrm{c}} \leq 6.5 \%$ or $<7 \%$ were similar for all treatment groups. Decreases in FPG were significantly lower for all treatment groups compared to placebo $(P<0.001$ for all) and ranged from 37 to $48 \mathrm{mg} / \mathrm{dL}$ for dulaglutide compared to $9 \mathrm{mg} / \mathrm{dL}$ for placebo. Weight loss was greatest in the $1 \mathrm{mg}$ titrated to $2 \mathrm{mg}$ dulaglutide group $(P<0.05)$ and overall greater weight loss was seen than for placebo $(P<0.05$ for all). The most frequent ADEs were nausea, diarrhea, and abdominal distention, and these were more frequent with the higher dulaglutide doses. Serious ADEs were noted in seven patients (one for placebo, three for $0.5 \mathrm{mg}$ titrated to $1 \mathrm{mg}$, two for $1 \mathrm{mg}$, and one for $1 \mathrm{mg}$ titrated to $2 \mathrm{mg}$ ) including hallucinations, cryptogenic organizing pneumonia, and pancreatitis (three episodes of which were possibly related to study drug and/or diabetes). The pancreatitis cases occurred in the $0.5 \mathrm{mg}$ titrated to $1 \mathrm{mg}$ group. Hypoglycemia was low but greater in the dulaglutide groups compared to placebo (weeks 4 and 12, $P<0.05$ ) with the rate decreasing over time; there was no significant difference at week 16 and no severe hypoglycemic events reported. Pulse and diastolic blood pressure were increased but systolic blood pressure was decreased in the dulaglutide groups, with no clinically significant ADEs noted due to vitals. In this study of overweight/obese T2DM patients, dulaglutide lowered the $A_{10}$ and FPG, while promoting weight loss with expected adverse effects for a once-weekly GLP-1 RA. 


\section{Compared to DPP-4 inhibitor}

Dulaglutide was compared to sitagliptin in 1,098 T2DM patients $\left(\mathrm{A}_{1 \mathrm{c}} 8.1 \%\right.$, duration of diabetes: 7 years) uncontrolled on metformin therapy in a double-blind, parallel-arm randomized study. ${ }^{17}$ Patients who were receiving metformin $(\geq 1,500 \mathrm{mg} /$ day $)$ with or without another oral antidiabetic medication were randomized to a dose-finding arm of dulaglutide, sitagliptin $100 \mathrm{mg} /$ day, or placebo, and after dosing were entered into either the dulaglutide $0.75 \mathrm{mg} /$ week or dulaglutide $1 \mathrm{mg}$ /week dosage arms for comparison to sitagliptin and placebo (replaced with sitagliptin at week 26 for blinding purposes) in a 2:2:2:1 ratio for a total of 104 weeks. The primary outcome was change in $\mathrm{A}_{1 \mathrm{c}}$ at 52 weeks. The LSm change in $A_{1 c}$ at week 52 revealed a greater decrease in $A_{1 c}$ for both dulaglutide arms (decrease of $0.87 \%-1.1 \%$ ) compared to sitagliptin (decrease of $0.39 \%, P<0.001$ ). More patients achieved an $\mathrm{A}_{1 \mathrm{c}}$ of $<7 \%$ and $\leq 6.5 \%$ in the dulaglutide arms compared to sitagliptin $(P<0.001$ for both $)$ at 52 weeks. The LSm change in FPG was less for sitagliptin compared to both doses of dulaglutide ( $P<0.001$ for both). At week 52, weight loss followed the same trend with greater reduction for dulaglutide $1.5 \mathrm{mg}$ and $0.75 \mathrm{mg}$ compared to sitagliptin $(P<0.001$ for both). The $\beta$-cell function as estimated by HOMA2-B increased in all arms at 52 weeks with significantly greater changes in dulaglutide compared to sitagliptin $(P<0.001)$. No differences were seen for HOMA2-S for insulin sensitivity. Dulaglutide produced a reduction in low-density lipoprotein (LDL) cholesterol whereas sitagliptin saw an increase at week 52 for a significant betweentreatment difference $(P=0.03)$. In terms of safety, a total of four patients died during the trial (one in the dulaglutide 1.5 $\mathrm{mg}$ arm, one in the sitagliptin arm, and two in the placebo arm [during the sitagliptin phase of the study]). Dulaglutide had a higher percentage of nausea, diarrhea, vomiting, and decreased appetite compared to sitagliptin $(P<0.05)$ with similar results compared to placebo. The GI adverse effects were worse during the first 2 weeks and declined over time. Discontinuation from the study due to medication ADEs at week 52 was similar across all arms, with hyperglycemia and nausea being the most common ADEs. Hypoglycemia occurrences were greatest for dulaglutide $1.5 \mathrm{mg}$ (10.2\%) followed by dulaglutide $0.75 \mathrm{mg}(5.3 \%)$ and then sitagliptin $(4.8 \%)$ at 52 weeks with no severe hypoglycemia reported during the study. Acute pancreatitis occurred in three patients (two on sitagliptin and one on placebo [during the sitagliptin phase]). Blood pressure also decreased in all treatment arms. Nine patients had treatment-emergent anti-dulaglutide antibodies noted during the treatment period (1.3\%) with no hypersensitivity events. Overall, dulaglutide lowered the $A_{1 c}$ and FPG greater than sitagliptin at week 52 with similar hypoglycemia and expected GI ADEs during this trial.

\section{Compared to other GLP-I RAs}

Dulaglutide has also been studied as add-on to pioglitazone and metformin compared to exenatide in a 52-week, parallel arm, randomized study in $976 \mathrm{~T} 2 \mathrm{DM}$ patients (baseline $\mathrm{A}_{1 \mathrm{c}}$ $8.1 \%$, duration of diabetes: 9 years). ${ }^{22}$ Patients were included if they were receiving monotherapy with one oral antidiabetic agent with an $A_{1 c}$ of $7 \%-11 \%$ or combination therapy with an $A_{1 c}$ of $7 \%-10 \%$. These oral antidiabetic agents were discontinued during the lead-in phase except for metformin or pioglitazone which were titrated up to $1,500-3,000 \mathrm{mg}$ daily and 30-45 mg daily, respectively. Patients were randomized in a 2:2:2:1 ratio to once-weekly dulaglutide $1.5 \mathrm{mg}$, onceweekly dulaglutide $0.75 \mathrm{mg}$, exenatide $5 \mu \mathrm{g}$ titrated up to $10 \mu \mathrm{g}$ twice daily, or placebo. The primary endpoint was change in $A_{1 c}$ at 26 weeks, which revealed a decrease by week 26 for all arms with the dulaglutide 1.5 and $0.75 \mathrm{mg}$ being superior to placebo $(P<0.001$ for both). Changes compared to exenatide were superior for dulaglutide 1.5 and $0.75 \mathrm{mg}$ arms ( $P<0.001$ for both). At 52 weeks, the changes in $\mathrm{A}_{1 \mathrm{c}}$ were also decreased in all arms with the dulaglutide 1.5 and $0.75 \mathrm{mg}$ being superior to exenatide ( $P<0.001$ for both). The percentage of patients reaching $\mathrm{A}_{1 \mathrm{c}}<7 \%$ and $\leq 6.5 \%$ at 26 weeks was higher for dulaglutide 1.5 and $0.75 \mathrm{mg}$ compared to exenatide $(P<0.001$ for both). Dulaglutide 1.5 and $0.75 \mathrm{mg}$ decreased FPG greater than exenatide at both $26(P<0.001$ for both) and 52 weeks ( $P \leq 0.05$ for both). Both dulaglutide arms demonstrated a greater reduction in preprandial blood glucose compared to placebo and exenatide $(P<0.001$ for both). The dulaglutide $1.5 \mathrm{mg}$ group had a greater reduction in all postprandial blood glucose values compared to exenatide $(P=0.047)$. Weight loss was significantly greater for the dulaglutide and exenatide groups compared to placebo at 26 weeks. HOMA2-B results at 26 weeks increased in dulaglutide and exenatide arms with greater increases in dulaglutide $1.5 \mathrm{mg}$ compared to exenatide $(P<0.001$ for all). No differences were noted for the HOMA2-S results. The dulaglutide $1.5 \mathrm{mg}$ arm showed a significant mean decrease in total and LDL cholesterol along with triglyceride levels compared with placebo at 26 weeks. Serious ADEs were similar in all groups, with two patients dying (one from myocardial infarction in the $1.5 \mathrm{mg}$ dulaglutide group and one from natural causes in the dulaglutide $0.75 \mathrm{mg}$ group) and overall incidence of ADEs was similar across all groups. GI ADEs were most commonly reported, with more in the 
dulaglutide $1.5 \mathrm{mg}$ and exenatide arms than in the dulaglutide $0.75 \mathrm{mg}$ arm. One patient in the dulaglutide $1.5 \mathrm{mg}$ group was diagnosed with chronic pancreatitis at 7 months with no previous history. Hypoglycemia occurred more in the exenatide group compared to the dulaglutide $1.5 \mathrm{mg}$ group $(P=0.007)$ with overall rates at 26 weeks of $10.4 \%$ in the dulaglutide $1.5 \mathrm{mg}$ arm, $10.7 \%$ in the dulaglutide $0.75 \mathrm{mg}$ arm, $15.9 \%$ in the exenatide arm, and $3.5 \%$ in the placebo arm. No severe hypoglycemia events were reported in the dulaglutide arms and two were reported in the exenatide arm. No significant changes in overall blood pressure were noted with any treatment groups. Ten $(1.8 \%)$ patients were positive for dulaglutide-developed treatment-emergent antidrug antibodies, but none reported systemic reactions. This trial revealed that dulaglutide provided greater glycemic control overall than exenatide twice daily and placebo. Similar ADEs were seen overall between dulaglutide and exenatide.

A head-to-head randomized, open-label, parallel-arm study comparing dulaglutide $1.5 \mathrm{mg}$ once-weekly to liraglutide 1.8 mg daily in 599 T2DM patients (baseline $\mathrm{A}_{1 \mathrm{c}} 8.1 \%$, duration of diabetes: 7.2 years) uncontrolled on metformin $1,500 \mathrm{mg}$ daily for $\geq 3$ months was conducted. ${ }^{23}$ The primary outcome was noninferiority for change in $\mathrm{A}_{1 \mathrm{c}}$ at 26 weeks with further efficacy and safety evaluated at the same time. Dulaglutide was shown to be noninferior to liraglutide with a between-group $\mathrm{A}_{1 \mathrm{c}}$ difference of $-0.06 \%$ (95\% confidence interval [CI], -0.19 to $0.07, P<0.001$ ) and individual decreases of $\mathrm{LSm}$ of $1.4 \%$ for dulaglutide and $1.36 \%$ for liraglutide $(P<0.0001$ from baseline for both). Similar percentages of patients receiving dulaglutide and liraglutide reached an $\mathrm{A}_{1 \mathrm{c}}$ of $<7 \%$ and $\leq 6.5 \%$. No difference was found between dulaglutide and liraglutide with decreases in FPG or postprandial glucose (LSm 46 versus $44 \mathrm{mg} / \mathrm{dL}$, respectively). Weight loss was greater with liraglutide compared to dulaglutide with a between-group difference of $0.71 \mathrm{~kg}(95 \% \mathrm{CI}, 0.17-1.26, P=0.011)$. Results for HOMA2-B were also similarly improved for both agents. Serious, but nonsigificant adverse drug reactions occurred in $2 \%$ of the dulaglutide group and $4 \%$ of the liraglutide group with no deaths and with similar rates of treatment-emergent ADEs. GI adverse effects were similar, mild to moderate in overall severity, and transient. There were no severe hypoglycemic events and rates for overall hypoglycemia were $9 \%$ for dulaglutide and $6 \%$ for liraglutide. No cases of pancreatitis or pancreatic cancer were reported. One cardiovascular event of a myocardial infarction occurred in the liraglutide group, and there were similar changes in both systolic and diastolic blood pressures and no differences in lipids between both groups. Treatment-emergent antibodies developed in three patients $(1 \%)$ in the dulaglutide group (not assessed in the liraglutide group) that did not develop into hypersensitivity reactions. Overall, dulaglutide $1.5 \mathrm{mg}$ once weekly demonstrated noninferiority for efficacy and safety to liraglutide $1.5 \mathrm{mg}$ daily.

\section{Future trials}

A review of dulaglutide at ClinicalTrials.gov reveals several ongoing trials, including studies comparing dulaglutide to placebo in patients already receiving sulfonylurea therapy (NCT01769378), glimepiride (NCT01644500), and oncedaily basal glargine insulin (NCT01648582). ${ }^{24-26}$ The primary outcome for each of these studies is change in $\mathrm{A}_{1 \mathrm{c}}$ at 24-26 weeks.

\section{Drug formulation and dosing}

Dulaglutide is dosed at $1.5 \mathrm{mg}$ and $0.75 \mathrm{mg}$ once-weekly as a subcutaneous injection based upon the AWARD-5 trial, which included a dose finding portion. ${ }^{17}$ Dulaglutide is to be delivered in a prefilled subcutaneous automatic injection device that will extend a needle, deliver dulaglutide, and retract the needle with the push of a button, and patients will not handle a needle. ${ }^{27}$

\section{Proposed benefits}

One advantageous benefit of GLP-1 agonists, including dulaglutide, is a potential increase in $\beta$-cell mass in vitro via increased cellular regeneration and inhibition of apoptosis - as seen in young rodent models - which leads to slower progression of T2DM and a potential delay in the need for insulin therapy. ${ }^{8,28}$ Although this was not shown to be detectable in older rodent models or human trials, there is evidence of preservation of $\beta$-cell function after 3 years of treatment with short acting exenatide. ${ }^{29}$ Studies currently completed with dulaglutide have shown an increase in $\beta$-cell function measured by an increase in HOMA2-B, but the insulin sensitivity marker HOMA2-S was not increased by dulaglutide as compared to placebo, sitagliptin, metformin, and exenatide twice daily. ${ }^{15,17,18,21,22}$ Furthermore, when compared head-to-head, dulaglutide and liraglutide both improved HOMA2-B. ${ }^{23}$ Overall, dulaglutide may slow the progression of T2DM and delay the need for insulin therapy through increasing HOMA2-B, but long-term data is not available.

GLP-1 agonists promote weight loss over conventional therapies for the treatment of T2DM with a moderate weight loss approximated at 1-3 kg (Table 1). ${ }^{15,17,18,21-23}$ Dulaglutide specifically reduced weight in a dose-dependent fashion 
by $0.2-2.5 \mathrm{~kg}$, compared to placebo. ${ }^{17,18}$ When compared to sitagliptin, dulaglutide produced greater weight reduction than sitagliptin. ${ }^{17}$ Weight-loss comparisons between dulaglutide $1.5 \mathrm{mg}$ and metformin 1,500-2,000 mg daily showed similar results. ${ }^{21}$ Compared with other GLP-1 RAs, dulaglutide at $1.5 \mathrm{mg}$ produced similar results to exenatide $10 \mu \mathrm{g}$ twice daily but statistically significant lower results compared to liraglutide $1.8 \mathrm{mg}$ daily. ${ }^{22,23}$

Since 2008, the United States Department of Health and Human Services FDA has provided guidance and recommendation that agents developed for the treatment of T2DM demonstrate that they do not cause increased or unacceptable cardiovascular risk. ${ }^{30}$ Exenatide (both formulations) and liraglutide have provided promising cardioprotective effects in animal models and early clinical studies, including reduced systolic blood pressure, LDL cholesterol, and triglycerides. ${ }^{31}$ Additionally, the rate of heart failure in patients receiving exenatide twice daily was lower than in patients receiving other treatments. ${ }^{31}$ In one retrospective study, patients with risk factors for cardiovascular disease who received exenatide were less likely to have a cardiovascular event. ${ }^{32}$ A recent meta-analysis that included 33 trials consisting of exenatide, exenatide long-acting, liraglutide, taspoglutide, and albiglutide demonstrated no increased major cardiovascular events (odds ratio $[\mathrm{OR}]=0.078[95 \%$ CI, 0.54-1.13], $P=0.18)$, myocardial infarctions $(\mathrm{OR}=0.87$ [95\% CI, 0.48-1.56], $P=0.63)$, strokes $(\mathrm{OR}=0.87$ [95\% CI, $0.37-2.05], P=0.75)$, or all-cause mortality $(\mathrm{OR}=0.89[95 \%$ CI, 0.46-1.70], $P=0.81) .{ }^{33}$ Compared to placebo, the GLP-1
RAs appeared to provide a potential benefit; however, the results were nonsignificant. Moreover, evidence exists that GLP-1 receptors are expressed within cardiomyocytes and arterial walls, and rodent models have demonstrated reduced infarct size and improved left-ventricular-ejection function during coronary ischemia when treated with a GLP-1 RA. ${ }^{8}$ No current studies have been published with major adverse cardiovascular events for dulaglutide. The Researching Cardiovascular Events With a Weekly Incretin in Diabetes (REWIND) trial (NCT01394952) is an ongoing trial that is randomizing patients with $\mathrm{T} 2 \mathrm{DM}$ and an $\mathrm{A}_{1 \mathrm{c}}$ of $\leq 9.5 \%$ to either dulaglutide $1.5 \mathrm{mg}$ every week or placebo, with the primary outcome of time from randomization to first occurrence of cardiovascular death, nonfatal myocardial infarction, or nonfatal stroke (a composite cardiovascular outcome); it is expected to be completed by April 2019. ${ }^{34}$

Cardiovascular safety endpoints, such as change in systolic and diastolic blood pressure for dulaglutide, have shown positive effects. Overall decreases in blood pressure have been minimal with only a few trials producing statistically significant, but not clinically significant, results (Table 2). ${ }^{15,17,18,21-23}$ The same is true for cholesterol, with decreases noted in LDL, triglycerides, and total cholesterol..$^{22,23}$

\section{Tolerability}

Adverse drug events of dulaglutide have been consistent with those of other agents in this class, with the most common seen being transient and mild GI side effects. These include nausea, vomiting, and diarrhea which are expected based

Table 2 Cardiovascular endpoints

\begin{tabular}{|c|c|c|c|c|c|}
\hline Study & $\begin{array}{l}\text { Average decrease } \\
\text { in systolic blood } \\
\text { pressure }(\mathrm{mmHg})\end{array}$ & $\begin{array}{l}\text { Average decrease } \\
\text { in diastolic blood } \\
\text { pressure }(\mathrm{mmHg})\end{array}$ & $\begin{array}{l}\text { Average decrease } \\
\text { in total cholesterol } \\
(\mathrm{mmol} / \mathrm{L})\end{array}$ & $\begin{array}{l}\text { Average decrease } \\
\text { in LDL cholesterol } \\
(\mathrm{mmol} / \mathrm{L})\end{array}$ & $\begin{array}{l}\text { Average decrease } \\
\text { in triglycerides } \\
(\mathrm{mmol} / \mathrm{L})\end{array}$ \\
\hline $\begin{array}{l}\text { Monotherapy - initial } \\
\text { or Metf failure }{ }^{15}\end{array}$ & $\begin{array}{l}\text { No difference } \\
\text { between groups }\end{array}$ & $\begin{array}{l}\text { No difference } \\
\text { between groups }\end{array}$ & $\begin{array}{l}\text { Not studied/ } \\
\text { reported }\end{array}$ & $\begin{array}{l}\text { Not studied/ } \\
\text { reported }\end{array}$ & $\begin{array}{l}\text { Not studied/ } \\
\text { reported }\end{array}$ \\
\hline $\begin{array}{l}\text { Monotherapy - prior Tx } \\
\text { with two OAM failure }{ }^{21} \\
\text { (26-wk data) }\end{array}$ & $\begin{array}{l}\text { No difference } \\
\text { between groups }\end{array}$ & $\begin{array}{l}\text { No difference } \\
\text { between groups }\end{array}$ & -2 to -4 (\% change $)$ & $\begin{array}{l}-3 \text { to }-7 \text { (\% change }) \\
(0.75 \mathrm{mg})^{\mathrm{a}}\end{array}$ & $\begin{array}{l}-2 \text { (\% change) } \\
(1.5 \mathrm{mg})^{\mathrm{a}}\end{array}$ \\
\hline $\begin{array}{l}\text { Combination therapy } \\
\text { with two OAM }{ }^{18}\end{array}$ & -0.6 to -3.0 & 0.2 to 1.2 & $\begin{array}{l}\text { Not studied/ } \\
\text { reported }\end{array}$ & $\begin{array}{l}\text { Not studied/ } \\
\text { reported }\end{array}$ & $\begin{array}{l}\text { Not studied/ } \\
\text { reported }\end{array}$ \\
\hline $\begin{array}{l}\text { Combination therapy } \\
\text { with Metf }{ }^{17} \text { (26-wk data) }\end{array}$ & -1.4 to $-1.7^{b}$ & -0.2 to -0.4 & $\begin{array}{l}-0.02 \text { to }-0.21 \\
(1.5 \mathrm{mg})^{c}\end{array}$ & $\begin{array}{l}-0.05 \text { to }-0.18 \\
(1.5 \mathrm{mg})^{\mathrm{c}, \mathrm{d}}\end{array}$ & -0.14 to -0.19 \\
\hline $\begin{array}{l}\text { Combination therapy } \\
\text { with Metf and } \mathrm{Pio}^{22} \\
\text { (26-wk data) }\end{array}$ & -0.36 to $0.11^{c}$ & 0.56 to 0.76 & $\begin{array}{l}-0.10 \text { to }-0.15 \\
(1.5 \mathrm{mg})^{\mathrm{b}}\end{array}$ & $\begin{array}{l}-0.08 \text { to }-0.11 \\
(1.5 \mathrm{mg})^{\mathrm{b}}\end{array}$ & $\begin{array}{l}-0.08 \text { to }-0.20 \\
(1.5 \mathrm{mg})^{\mathrm{b}, \mathrm{e}}\end{array}$ \\
\hline $\begin{array}{l}\text { Combination therapy } \\
\text { with } \text { Metf }^{23}\end{array}$ & -3.36 & -0.22 & $\begin{array}{l}\text { No difference } \\
\text { observed }\end{array}$ & $\begin{array}{l}\text { No difference } \\
\text { observed }\end{array}$ & $\begin{array}{l}\text { No difference } \\
\text { observed }\end{array}$ \\
\hline
\end{tabular}

Notes: ${ }^{a} P<0.05$ versus metformin; ${ }^{b} P<0.005$ versus placebo; ${ }^{c} P<0.001$ versus placebo; ${ }^{d} P<0.05$ versus sitagliptin and $p$ lacebo; ${ }^{e} P<0.05$ versus exenatide.

Abbreviations: LDL, low-density lipoprotein; Metf, metformin; OAM, oral antidiabetic medications; Pio, pioglitazone; Tx, treatment; wk, week. 
upon the mechanism of action and usually decrease over time. Hypoglycemia is similar to other GLP-1 RAs and was typically not significant in the clinical trials, with no reports of severe hypoglycemia occurring in any trial. ${ }^{15,17,18,21-23}$ Injection-site reactions are also possible but have not been reported at a high rate in currently available clinical trials. Development of antibodies against the medication may potentially lead to reduced efficacy and/or changes in the safety profile. The risk with dulaglutide in clinical trials appears to be low according to currently available trials but varied from study to study from no reports to up to ten reports. ${ }^{15,17,18,21-23}$ Out of the reported cases, only one hypersensitivity reaction occurred resulting in treatment-emergent skin rash and skin exfoliation. ${ }^{15}$

Pancreatitis is a concern for all incretin agents. In March 2013, the FDA released a drug-safety communication describing the risk of pancreatitis with these agents. This communication was in response to postmarketing reports of acute pancreatitis with exenatide and sitaglipitn along with results from a population-based matched case-control study demonstrating increased risk for hospitalization with acute pancreatitis from sitagliptin and exenatide. ${ }^{35}$ This study found that T2DM patients who had pancreatitis and were taking these two incretin agents were more likely to have hypertriglyceridemia, increased alcohol use, gallstones, tobacco abuse, obesity, biliary and pancreatic cancer, cystic fibrosis, and any neoplasm compared to controls. After adjusting for confounders, including specifically metformin therapy, the association for risk of acute pancreatitis was higher in those having ever taken sitagliptin and exenatide (adjusted OR, 2.07 [95\% CI, 1.36-3.13], $P=0.01$ ). However, a metaanalysis published in February 2014 reviewed 80 studies and included 41 studies in an analysis of 14,972 patients; it found the overall risk of pancreatitis was not different between GLP-1 RAs and comparators (OR,1.01 [95\% CI, 0.37-2.76], $P=0.99) .{ }^{36}$ In another meta-analysis of randomized and nonrandomized trials, prospective and retrospective cohort studies, and case-controlled studies of treatment with GLP-1 RAs or DPP-4 inhibitors in T2DM patients, the risk for pancreatitis was compared to placebo, lifestyle modification, or oral antidiabetic medications. ${ }^{37}$ A total of 60 studies were included and, from the 55 randomized controlled trials, there was no increased risk for pancreatitis seen for the incretin therapies (OR, 1.11 [95\% CI, 0.57-2.17]). Overall, the risk in currently available clinical trials is inconclusive as there have been either no cases reported, or one to two cases which may have been related to the study drug. In addition it should be noted that patients with diabetes have an associated higher rate of pancreatitis. A meta-analysis of T2DM patients revealed an increased relative risk of 1.8 (95\% CI, 1.45-2.33, $P=0.000){ }^{38}$

Along with approval of this agent, the FDA has mandated a risk evaluation and mitigation strategy to be completed postmarketing to monitor and lessen the potential risk of pancreatitis and medullary thyroid carcinoma. ${ }^{39}$ These risk evaluation and mitigation strategies are required for all GLP-1 RAs currently available on the market in the United States. The risk for medullary thyroid cancers is because thyroid C-cell tumors have been seen in rodent studies with other GLP-1 RAs. ${ }^{39}$

\section{Economic considerations}

GLP-1 RAs are expensive agents for T2DM therapy. Currently, data and pricing information for dulaglutide is comparative to mid-range GLP-1 agonists on the market. GLP-1 therapies range from $\$ 391$ to $\$ 706$ based on average wholesale price package price information (Table 3). ${ }^{40}$

A recent retrospective cohort study using medical and pharmacy claims examined per-patient costs of glycemic control in adult patients naïve to incretin therapies who had a baseline $\mathrm{A}_{1 \mathrm{c}}$ average of $7.8 \% .{ }^{41}$ This study examined the cost of reducing $\mathrm{A}_{1 \mathrm{c}}$ to $<7 \%$ with liraglutide or exenatide twice daily. Unadjusted cost for total diabetes-related pharmacy was similar for patients who received liraglutide compared to exenatide ( $\$ 1,993$ versus $\$ 1,924, P=0.376)$. When age, sex, baseline $\mathrm{A}_{1 \mathrm{c}}$, comorbidity history, and concomitant medication-use factors were controlled for, the exenatide group had lower diabetes-related pharmacy costs per patient than the liraglutide group (estimated \$203.1 difference in cost; $P=0.0002$ ). Additionally, the liraglutide

Table 3 Price comparison of currently available GLP-I RAs

\begin{tabular}{|c|c|c|}
\hline Name & $\begin{array}{l}\text { Dose and } \\
\text { concentration }\end{array}$ & $\begin{array}{l}\text { AWP per } \\
\text { package }\end{array}$ \\
\hline Exenatide (Byetta $\left.{ }^{\circledR}\right)$ & $250 \mu \mathrm{g} / \mathrm{mL}, 1.2 \mathrm{~mL}$ & $\$ 5|2.5|$ \\
\hline Exenatide $\left(\right.$ Byetta $\left.^{\circledR}\right)$ & $250 \mu \mathrm{g} / \mathrm{mL}, 2.4 \mathrm{~mL}$ & $\$ 5|2.5|$ \\
\hline $\begin{array}{l}\text { Exenatide long-acting } \\
\left.\text { (Bydureon }^{\circledR}\right)\end{array}$ & $2 \mathrm{mg}$ & $\$ 528.06$ \\
\hline Liraglutide (Victoza ${ }^{\circledR}$ ) & $6 \mathrm{mg} / \mathrm{mL}$ & $\$ 706.32$ \\
\hline Albiglutide (Tanzeum ${ }^{\mathrm{TM}}$ ) & $30 \mathrm{mg}$ & $\$ 391.15$ \\
\hline Albiglutide (Tanzeum ${ }^{\mathrm{TM}}$ ) & $50 \mathrm{mg}$ & $\$ 391.15$ \\
\hline Dulaglutide (Trulicity ${ }^{\mathrm{TM}}$ ) & $0.75 \mathrm{mg} / 0.5 \mathrm{~mL}$ & $\$ 585.98$ \\
\hline Dulaglutide (Trulicity ${ }^{\mathrm{TM}}$ ) & $1.5 \mathrm{mg} / 0.5 \mathrm{~mL}$ & $\$ 585.98$ \\
\hline
\end{tabular}

Note: Data from Redbook system. Available from: http://www.redbook.com/ redbookl. ${ }^{40}$

Abbreviations: AWP, average wholesale price; GLP-I RAs, glucagon-like peptidereceptor agonist. 
group had a higher predictive diabetes related pharmacy cost per patient than the exenatide group $(\$ 2,002 \pm \$ 502$ for liraglutide versus $\$ 1,799 \pm \$ 502$ for exenatide, $P<0.001$ ), but more patients in the liraglutide group reached $\mathrm{A}_{1 \mathrm{c}}$ of $<7 \%$. With this, cost per patient successfully achieving $\mathrm{A}_{1 \mathrm{c}}$ of $<7 \%$ (cost for control) was lower with liraglutide compared to exenatide $(\$ 3,108 \pm \$ 779$ versus $\$ 3,354 \pm \$ 936$, $P<0.0001)$. Since dulaglutide is a long-acting GLP-1 similar to liraglutide, clinicians may see results similar to liraglutide when dulaglutide comes to market. However, further clinical trials are needed to examine this specifically for dulaglutide.

\section{Conclusion}

Dulaglutide is a GLP-1 RA that has demonstrated $\mathrm{A}_{1 \mathrm{c}}$ reduction of $\sim 0.7 \%-1.5 \%$ and reductions of FPG by $13-43 \mathrm{mg} / \mathrm{dL}$, as monotherapy or in combination, at 0.75 and $1.5 \mathrm{mg}$ once-weekly doses in clinical trials. Compared to other GLP-1 RAs in the class, it has been shown to be overall noninferior for both safety and efficacy. Safety concerns are similar to other agents in the class, with similarly low risk for hypoglycemia and the most common ADEs being transient GI problems. Similar to other agents in the class, it has demonstrated weight loss of $\sim 1.3-3 \mathrm{~kg}$ which has been sustained over at least 26 weeks. There are still questions remaining about long-term efficacy and safety, including major cardiovascular events which are currently being researched, but dulaglutide has not demonstrated a significant increased risk for pancreatitis or pancreatic cancer in short-term trials. Overall, it should be located alongside the other long-acting agents in the GLP-1 RA class within the recommended guidelines.

\section{Disclosure}

The authors report no conflicts of interest in this work.

\section{References}

1. Diabetes facts and figures [webpage on the Internet]. Brussels: International Diabetes Federation; 2014. Available from: http://www.idf. org/worlddiabetesday/toolkit/gp/facts-figures. Accessed June 12, 2014.

2. Lovshin JA, Drucker DJ. Incretin-based therapies for type 2 diabetes mellitus. Nat Rev Endocrinol. 2009;5:262-269.

3. Scheen AJ. GLP-1 receptor agonists or DPP-4 inhibitors: how to guide the clinician?. Ann Endocrinol (Paris). 2013;74:515-522.

4. Drab SR. Incretin-based therapies for type 2 diabetes mellitus: current status and future prospects. Pharmacotherapy. 2010;30:609-624.

5. Inzucchi SE, Bergenstal RM, Buse JM, et al. Management of hyperglycemia in type 2 diabetes: a patient-centered approach. Position statement of the American Diabetes Association (ADA) and the European Association for the Study of Diabetes (EASD). Diabetologia. 2012;55:1577-1596.

6. Garber AJ, Abrahamson MJ, Barzilay JI, et al. AACE comprehensive diabetes management algorithm 2013. Endocr Pract. 2013;19: 327-336.
7. National Institute for Health and Clinical Excellence. The Management of Type 2 Diabetes, NICE Clinical Guideline 87, 2009. Available from: https://www.nice.org.uk/guidance/cg87. Accessed June 4, 2014.

8. Meier JJ. GLP-1 receptor agonists for individualized treatment of type 2 diabetes mellitus. Nat Rev Endocrinol. 2012;8:728-742.

9. Drucker D, Sherman SI, Gorelick FS, Bergenstal RM, Sherwin RS, Buse JB. Incretin-based therapies for the treatment of type 2 diabetes: evaluation of the risks and benefits. Diabetes Care. 2010;33: 428-433.

10. DeFranzo RA, Ratner RE, Han J, Kim DD, Fineman MS, Baron AD. Effects of exenatide (exendin-4) on glycemic control and weight over 30 weeks in metformin-treated patients with type 2 diabetes. Diabetes Care. 2005;28:1092-1100.

11. Buse JB, Henry RR, Han J, et al. Effects of exenatide (exendin-4) on glycemic control over 30 weeks in sulfonylurea-treated patients with type 2 diabetes. Diabetes Care. 2004;27:2628-2635.

12. Garber A, Henry RR, Ratner R, et al. Liraglutide, a once-daily human glucagon-like peptide-1 analogue, provides sustained improvements in glycaemic control and weight for 2 years as monotherapy compared with glimepiride in patients with type 2 diabetes. Diabetes Obes Metab. 2011;13:348-356.

13. Zinman B, Gerich J, Buse JB, et al. Efficacy and safety of the human glucagon-like peptide-1 analog liraglutide in combination with metformin and thiazolidinedione in patients with type 2 diabetes (LEAD-4 Met + TZD). Diabetes Care. 2009;32:1224-1230.

14. Russell-Jones D, Vaag A, Schmitz O, et al. Liraglutide vs insulin glargine and placebo in combination with metformin and sulfonylurea therapy in type 2 diabetes mellitus (LEAD-5 met+SU): a randomised controlled trial. Diabetologia. 2009;52:2046-2055.

15. Grunberger G, Chang A, Garcia Soria G, Botros FT, Bsharat R, Milicevic Z. Monotherapy with the once-weekly GLP-1 analogue dulaglutide for 12 weeks in patients with Type 2 diabetes: dose-dependent effects on glycaemic control in randomized, double-blind, placebocontrolled study. Diabet Med. 2012;29:1260-1267.

16. Barrington P, Chien JY, Showalter HD, et al. A 5-week study of the pharmacokinetics and pharmacodynamics of LY2189265, a novel, long-acting, glucagon-like peptide-1 analogue, in patients with type 2 diabetes. Diabetes Obes Metab. 2011;13:426-433.

17. Nauck M, Weinstock RS, Umpierrez GE, Guerci B, Skivanek Z, Milicevic Z. Efficacy and safety of dulaglutide versus sitagliptin after 52 weeks in type 2 diabetes in a randomized controlled trial (AWARD-5). Diabetes Care. 2014;37:2149-2158.

18. Umpierrez GE, Blevins T, Rosenstock J, et al. The effects of LY2189265, a long-acting glucagon-like peptide-1 analogue, in a randomized, placebo controlled, double-blind study of overweight/obese patients with type 2 diabetes: the EGO study. Diabetes Obes Metab. 2011;13:418-425.

19. Lorenz M, Evers A, Wagner M. Recent progress and future options in the development of GLP-1 receptor agonists for the treatment of diabesity. Bioorg Med Chem Lett. 2013;23:4011-4018.

20. Institute for Quality and Efficiency in Health Care: Executive Summaries [Internet]. Evaluation of the therapeutic benefits and harms of exenatide: executive summary of final report A05-23, version 1.0. Available from: https://www.iqwig.de/download/A05-23_Executive_Summary_ Evaluation_of_the_therapeutic_benefits_and_harms_of_exenatide.pdf. Accessed November 7, 2014.

21. Umpierrez G, Tofé Povedano S, Pérez Manghi F, Shurzinske L, Pechtner V. Efficacy and safety of dulaglutide monotherapy versus metformin in type 2 diabetes in a randomized controlled trial (AWARD-3). Diabetes Care. 2014;37:2168-2176.

22. Wysham C, Blevins T, Arakaki, et al. Efficacy and safety of dulaglutide added onto pioglitazone and metformin versus exenatide in type 2 diabetes in a randomized controlled trial (AWARD-1). Diabetes Care. 2014;37:2159-2167.

23. Dungan KM, Povedano ST, Forst T, et al. Once-weekly dulaglutide versus once-daily liraglutide in metformin-treated patients with type 2 diabetes (AWARD-6): a randomized, open-label, phase 3, non-inferiority trial. Lancet. 2014;384(9951):1349-1357. 
24. Eli Lilly and Company. A randomized, parallel-arm, double-blinded study comparing the effect of once-weekly dulaglutide with placebo in patients with type 2 diabetes on sulfonylurea therapy (AWARD-8: Assessment of weekly administration of LY2189265 in diabetes - 8). Available from: http://clinicaltrials.gov/show/NCT01769378. NLM identifier: NCT01769378. Accessed June 4, 2014.

25. Eli Lilly and Company. The efficacy and safety of once-weekly, subcutaneous dulaglutide monotherapy compared with glimepiride in patients with type 2 diabetes mellitus. Available from: http://clinicaltrials.gov/show/ NCT01644500. NLM identifier: NCT01644500. Accessed June 4, 2014.

26. Eli Lilly and Company. The efficacy and safety of once-weekly, subcutaneous dulaglutide compared to once-daily insulin glargine in patients with type 2 diabetes mellitus on metformin and/or a sulfonyluea. Available from: http://clinicaltrials.gov/show/NCT01648582. NLM identifier: NCT01648582. Accessed June 4, 2014.

27. Eli Lilly submits GLP-1 dulaglutide to FDA and unveils injection device [webpage on the Internet]. San Francisco: DiaTribe; 2013. Available from: http://diatribe.org/issues/59/new-now-next/5. Accessed August 13, 2014.

28. Garber AJ. Incretin effects on $\beta$-cell function, replication, and mass: the human perspective. Diabetes Care. 2011;34 Supp1 2:s258-s263.

29. Bunck MC, Corner A, Eliasson B, et al. Effects of exenatide on measures of $\beta$-cell function after 3 years in metformin-treated patients with type 2 diabetes. Diabetes Care. 2011;34:2041-2047.

30. Guidance for industry diabetes mellitus - evaluating cardiovascular risk in new antidiabetic therapies to treat type 2 diabetes [webpage on the Internet]. US Department of Health and Human Services Food and Drug Administration Center for Drug Evaluation and Research (CDER) [updated 2008]. Available from: http://www.fda.gov/downloads/drugs/ guidancecomplianceregulatoryinformation/guidances/ucm071627.pdf. Accessed June 12, 2014.

31. Mundil D, Cameron-Vendrig A, Husain M. GLP-1 receptor agonists: a clinical perspective on cardiovascular effects. Diab Vasc Dis Res. 2012;9:95-108.

32. Best JH, Hoogwerf BJ, Herman WH, et al. Risk of cardiovascular disease events in patients with type 2 diabetes prescribed the glucagonlike peptide-1 (GLP-1) receptor agonist exenatide twice daily or other glucose-lowering therapies: a retrospective analysis of the LifeLink database. Diabetes Care. 2011;34:90-95.
33. Monami M, Dicembrini I, Nardini C, Fiordelli I, Mannucci E. Effects of glucagon-like peptide-1 receptor agonists on cardiovascular risk: a meta-analysis of randomized clinical trials. Diabetes Obes Metab. 2014;16:38-47.

34. Eli Lilly and Company. The effect of dulaglutide on major cardiovascular events in patients with type 2 diabetes: Researching cardiovascular events with a weekly incretin in diabetes (REWIND). Available from: http://clinicaltrials.gov/show/NCT01394952. NLM identifier: NCT01394952. Accessed June 12, 2014.

35. Singh S, Chang HY, Richards TM, Weiner JP, Clark JM, Segal JB. Glucagonlike peptide-1 based therapies and risk of hospitalization for acute pancreatitis in type 2 diabetes mellitus: a population-based matched case-control study. JAMA Intern Med. 2013;173:534-539.

36. Monami M, Dicembrini I, Naradini C, Fiordelli I, Mannucci E. Glucagon-like peptide-1 receptor agonists and pancreatitis: a metaanalysis of randomized clinical trials. Diabetes Res Clin Pract. 2014;103:269-275.

37. Li L, Shen J, Bala MM, et al. Incretin treatment and risk of pancreatitis in patients with type 2 diabetes mellitus: systematic review and metaanalysis of randomised and non-randomised studies. BMJ. 2014;348: g2366.

38. Yang L, He Z, Tang X, Liu J. Type 2 diabetes mellitus and the risk of acute pancreatitis: a meta-analysis. Eur J Gastroenterol Hepatol. 2013;25:225-231.

39. Eli Lilly and Company. BLA 125469 TRULICITYTм (Dulaglutide) Glucagon-like Peptide-1 (GLP-1) Receptor Agonist: RISK EVALUATION AND MITIGATION STRATEGY (REMS). Available from: http:// www.fda.gov/downloads/Drugs/DrugSafety/PostmarketDrugSafety InformationforPatientsandProviders/UCM417230.pdf. Accessed October 3, 2014.

40. Redbook system [database on the Internet]. Greenwood Village, CO: Truven Health Analytics; 2014. Available from: http://www.redbook. com/redbook/. Accessed November 21, 2014.

41. DeKoven M, Lee WC, Bouchard J, Massoudi M, Langer J. Real-world cost-effectiveness: lower cost of treating patients to glycemic goal with liraglutide versus exenatide. Adv Ther. 2014;31:202-216.
Core Evidence

\section{Publish your work in this journal}

Core Evidence is an international, peer-reviewed open-access journal evaluating the evidence underlying the potential place in therapy of drugs throughout their development lifecycle from preclinical to postlaunch. The focus of each review is to evaluate the case for a new drug or class in outcome terms in specific indications and patient groups.

\section{Dovepress}

The manuscript management system is completely online and includes a very quick and fair peer-review system, which is all easy to use. Visit http://www.dovepress.com/testimonials.php to read real quotes from published authors. 